Jurnal Bisnis dan Manajemen, Volume 19, No. 2, September 2018, p. 109-121

\title{
JOB BURNOUT: A MEDIATION BETWEEN EMOTIONAL INTELLIGENCE AND TURNOVER INTENTION
}

\author{
Kartono ${ }^{1}$, Hilmiana ${ }^{2}$ \\ ${ }^{1}$ Universitas Swadaya Gunung Jati, Indonesia \\ ${ }^{2}$ Universitas Padjadjaran, Indonesia
}

\begin{abstract}
The emotional intelligence of employees can make employees have the desire to the turnover intention which can also be influenced by the level of job burnout employees. This research aims to investigate the effect of emotional intelligence on the turnover intention with job burnout as the mediating variable. This study uses a quantitative analysis method which aims to analyze the relationship between the observed variables and to confirm the theory using PLS-SEM analysis (Partial Least Square - Structural Equation Modeling). Respondent consists of 233 employees of PD. Bank BPR West Java who were selected using random sampling technique. The results showed that emotional intelligence, consisting of social competence and personal competence, positively affect turnover intention, characterized by the behaviors of thinking to quit, job search, and intending to quit. Emotional intelligence, consisting of social competence and personal competence, positively influences job burnout which can be seen from the aspect of exhaustion, depersonalization, and declining achievement. Employees experiencing a high level of emotional exhaustion will be likely to quit and look for new career opportunities. In other words, the higher the level of job burnout is, the higher the tendency of the employee to quit becomes.
\end{abstract}

Keywords: Emotional Intelligence, Job Burnout, Turnover Intention

\section{JOB BURNOUT: MEDIASI KECERDASAN EMOSIONAL TERHADAP TURNOVER INTENTION}

\begin{abstract}
ABSTRAK
Penelitian ini bertujuan untuk menguji pengaruh kecerdasan emosional terhadap Turnover Intention dengan Job Burnout sebagai variabel mediasi. Penelitian ini menggunakan metode kuantitatif yang bertujuan untuk analisis ada tidaknya hubungan antar variabel yang diteliti dan untuk mengkonfirmasi teori dengan analisis PLS-SEM (Partial Least Square - Structural Equation Modelling). Sampel pada peneitian ini sebanyak 233 responden pegawai di PD. Bank Perkreditan Rakyat (BPR) Jawa Barat yang diambil secara random sampling. Hasil penelitian menunjukkan bahwa kecerdasan emosional yang terdiri dari kompetensi sosial dan kompetensi personal berpengaruh positif terhadap turnover intention yang ditandai dengan perilaku thinking to quit, job search, dan intent to quit. Kecerdasan emosional, yaitu; kompetensi sosial dan kompetensi personal mempengaruhi secara positif kelelahan pegawai yang dapat dilihat dari aspek kelelahan, depersonalisasi, dan penurunan prestasi. Pegawai yang mengalami tingkat kelelahan emosional yang tinggi dapat memungkinkan untuk meninggalkan organisasi atau keluar dari perusahaan dan mencari peluang karir baru atau dengan semakin tinggi tingkat kelelahan kerja seorang pegawai maka kecenderungan pegawai untuk keluar dari organisasi (turnover intention) semakin tinggi.
\end{abstract}

Kata-kata kunci: Job Burnout, Kecerdasan Emosional, Turnover Intention

Korespondensi: Kartono. Universitas Swadaya Gunung Jati. J1. Pemuda No. 32 Kota Cirebon. 45152.

Email: kartono.unswagati@gmail.com

Submitted: June 2018, Accepted: September 2018, Published: September 2018

ISSN: 1412 - 3681 (printed), ISSN: 2442 - 4617 (online), Website: http://journal.feb.unpad.ac.id/index.php/jbm 
Jurnal Bisnis dan Manajemen, Volume 19, No. 2, September 2018, p. 109-121

\section{INTRODUCTION}

In this globally competitive era, companies are required to anticipate changes in the organization's environment, both internal and external. They need to have the excellent responsiveness and be adaptive to the changing and more competitive market environment. Currently, in Indonesia, there are 75,491 Rural Banks (BPR) recorded until October 2014 (Bank Indonesia, 2014). Thus, the number of BPR in Indonesia certainly increases competition among BPR.

The problem of low competitiveness of BPR compared with other financial services is caused by several factors, such as; external and internal factors. The external factors are an economic condition, government regulation, and inflation, while the internal factors are things related to Human Resouces (HR) issues. These internal and external factors do have implications for the quality and quantity of HR available at the Bank BPR.

The internal factors in PD. Bank BPR related to human resource issues which are influenced by many factors, such as; integrity and governance remuneration, availability of human resources, and the image of BPR (Heru Santoso, 2012).

The first factor affecting the quality and quantity of human resources of PD. Bank BPR is integrity and governance, namely HR policies and inadequate internal controls, fraud which is a major cause of BPR bankruptcy, and dual role as owner and management in most of BPR(s).
The second factor is remuneration such as a relatively low salary (below the minimum level), small benefit packages, and the limited career path and growth opportunities to enhance competence.

The third factor is the availability of human resources, such as the difficulty to find the right human resources in certain areas, and the expectation of prospective employees exceeding the capabilities of the BPR.

The fourth factor is the image of the BPR, such as the fact that people are more proud of working in a commercial bank, limited understanding of people about the business BPR, and the limited confidence of the public in BPR (Heru Santoso, 2012).

Some of the above factors, such as integrity \& governance, remuneration, human resources availability, BPR image is a factor that can cause employee turnover in PD. Bank BPR (Heru Santoso, 2012).

The turnover intention in an organization is usually caused by the individual's desires caused by various factors. These factors consist of internal and external factors. Internal factors include motivation, educational background, working experience, geographical condition, social and organizational support, job satisfaction, attachment, fatigue or burnout, personality, and emotional intelligence (Wahyuni, Zaika, \& Anwar, 2014).

On the other hand, the external factors include salary/wages, incentives, the attitude of superordinate, supporting space and facilities, job 
Jurnal Bisnis dan Manajemen, Volume 19, No. 2, September 2018, p. 109-121

promotion, organizational culture, working environment, career opportunities outside the company, commitment, and social relationship (Wahyuni et al., 2014).

Galit Meisler (2013) showed that emotional intelligence positively affects the organizational fairness, but negatively affects turnover intention. On the other hand, a poor working condition, low wages, working hour exceeding the limit, the absence of social security and fairness in the workplace are the major causes of turnover (Ongori, 2007).

Moreover, Wang (2014) found that active commitment is an essential factor to prevent emotional exhaustion and turnover intention. The continuous commitment positively affects the emotional exhaustion of employees.

Mayende \& Musenze (2014) studied the relationship of emotional intelligence with turnover intention. Where the results of his research (Mayende \& Musenze, 2014) explain that employees who have high emotional intelligence will tend to leave work, while employees who have a low level of emotional intelligence will be more likely to remain in the company.

Dotun, Nneka, \& Akinlolu (2013) explained that there is a significant positive relationship between work fatigue and turnover intention. Employees who experience fatigue based on different factors, such as; biographical and personality and there is a positive correlation between age, education level, years of experience, and work fatigue with turnover intention.
From some of the research results above, there are differences in research findings in looking at emotional intelligence towards turnover intention, both directly and through mediation variables with other variables. So that by taking different settings from previous studies, to test empirically antecedents that affect the level of turnover intention, the research problem to be examined in this study is to focus on how fatigue in mediating emotional intelligence to employee turnover intention in PD. Rural Bank (BPR) in West Java.

\section{LITERATURE REVIEW Emotional Intelligence}

Social intelligence is an inherent ability, motivation, behavior of individuals and others as well as the best function based on information obtained (Thorndike in (Khanifar, Maleki, Nazari, \& Emami, 2012). While Khanifar et al. (2012) stated that emotional intelligence is a person's ability to adapt to the environment which can be seen from several elements, namely; selfregulatory, self-consciousness, self-motivating, sympathy, and social skills.

Other scholars have a different perspective in defining emotional intelligence. BarOn R. \& Parker (2000) considered that emotional intelligence is the intelligence generated from emotions and thoughts. This reaches a general emotional construction, personal, and social skills affecting the ability to cope with stress and environmental demands (Chiva.R \& Alegre.J, 2008). 
Jurnal Bisnis dan Manajemen, Volume 19, No. 2, September 2018, p. 109-121

The necessary components of emotional intelligence are the ability to understand the emotions of self and others, as well as the ability to organize and control themselves and others in a way that is adaptive and responsive. An individual with high emotional intelligence is capable of making social adaptation and better social skills (Khanifar et al., 2012). Thus, he or she is the facilitator for social life as he or she can help people have a useful interaction and mutual benefit with others. In addition, an individual demonstrating good social skills will behave well so that other people will like him or her (Palmer, Donaldson, \& Stough, 2008).

On the other hand, Robbins (2007) stated that emotional intelligence is a person's ability to detect and process instructions and emotional information. Emotional intelligence consists of five dimensions, including self-consciousness which is the ability to know what is felt, selfcontrol refers is the ability to control his own emotion so it has a positive impact on the task being done, motivation is the ability to use the desire to move and guide himself towards the target, empathy which defined as the ability to feel other people's feelings and understand the perspectives of others, and social skill which is the ability to well respond to the emotions when interacting with someone, to carefully read the situation and social network, and to interact or work together smoothly.

Emotional intelligence is beneficial to ourselves and others because we can build a relationship maturely and constructively.
Emotional intelligence can be measured in two dimensions, namely personal competence and social competence. Personal competence can be seen through self-awareness and self-management while social competence can be seen in social awareness and relational management (Kreitner, R., \& Kinicki, 2014).

(Pishghadam \& Sahebjam, 2012), in their study of personality and emotional intelligence in fatigue phenomena experienced by teachers, used an adaptation of Persian Bar On-EQI (BarOn, 1997) to measure emotional intelligence It consists of intrapersonal, adaptability, general mood, interpersonal, and stress management.

Ravichandran, Arasu, \& Arun Kumar (2011) described that emotional intelligence is an emotion regulation involving the ability to assess and adjust the mood of a person with another person, based on some abilities to control emotion. While Ravichandran et al. (2011) suggested that a person's emotional intelligence can be seen from some of the skills, namely the ability to perceive and appraise emotion, assimilating skill, skill in understanding and analyzing emotion, and self-adapting.

Meanwhile, Green, Miller, \& Aarons (2013) stated that emotional exhaustion could negatively affect performance. Physical exhaustion and emotional exhaustion will affect employees' performance and client satisfaction. Emotional exhaustion has a positive effect on turnover intention while the transformational leadership has a negative effect on both emotional exhaustion and turnover intention. 
Jurnal Bisnis dan Manajemen, Volume 19, No. 2, September 2018, p. 109-121

Wang (2014) studied the effect of commitment, emotional exhaustion, and turnover intention. He found that social and financial ties influence affective commitment while structural and financial ties affect continuance commitment. Furthermore, affective commitment is an essential factor to prevent emotional exhaustion and turnover intention, while the continuous commitment positively affects emotional exhaustion.

\section{Job Burnout}

Job Demand-Resource model (JD-R) is a theory which has been widely known and used to describe the process of employee's fatigue (Demerouti, Nachreiner, Bakker, \& Schaufeli, 2001, Hakanen, Bakker, \& Schaufeli, 2006). In general, the job demands result in fatigue by requiring employees to exert their physical and psychological efforts. However, work resources such as social support, autonomy, and supervision can reduce the job demands thus those resources can reduce the fatigue felt by employees.

Hakanen et al. (2006) described burnout as a specific form of job stress of an employee working in the field of social services as a result of the emotional demands when interacting with customers.

Kim, Shin, \& Swanger (2009) defined the concept of burnout using only two sub-dimensions (exhaustion and cynicism) and the attachment using four sub-factors (passion, dedication, absorption, and professional success).
Burnout is part of physical, emotional, and mental exhaustion caused by the individual's long-term involvement in a situation which is full of emotional demands (Demerouti et al., 2001). Meanwhile, Maslach, C., \& Leiter (2008) stated that burnout could be caused by two factors, namely situational factors and individual factors. Situational factors consist of job characteristics, position characteristics and organizational characteristics. Meanwhile, individual factors consist of demographics, personal characteristics, and work ethic. The dimensions of burnout are exhaustion, cynicism, and low personal accomplishment (Maslach, C., \& Leiter, 2008). Exhaustion is characterized by prolonged fatigue physically, such as headaches, colds, and insomnia, mentally such as unhappy feeling and failure feeling, emotionally such as bored, sad, and depressed. Depersonalization is cynicism towards other people in the work environment and a tendency to isolate and reduce involvement in the work. Low personal accomplishment is characterized by feelings of dissatisfaction with one's worth, occupation, and life leading to inferiority with self-competence and achievement of personal goals.

However, Shirom, A., Melamed, S., Toker, S., Berliner, S., \& Shapira (2005) explained that the burnout includes three interrelated aspects, namely physical, emotional and cognitive exhaustion. Physical exhaustion is associated with a lack of energy to cope with everyday tasks. Emotional exhaustion is associated with a lack of enthusiasm for carrying 
Jurnal Bisnis dan Manajemen, Volume 19, No. 2, September 2018, p. 109-121

out tasks related to affection in the workplace, including the process of building and strengthening the interpersonal relationship with co-workers. The last component of the Shirom taxonomy is cognitive exhaustion characterized by difficulty in concentrating and thinking in a normal way. To sum up, based on Shirom (2003), burnout is the cumulative consequence of the three types of exhaustion which are gradually formed in individuals over time, and this is not the result of one component in a short time.

Also, Chen \& Yu (2014) showed that job demands and labor job resources have a significant effect on burnout. Furthermore, job resources have a significant and positive effect on organizational commitment. While burnout and organizational commitment have a significant influence on the turnover intention.

From the concepts above, it can be explained that the burnout is an individual state of physical, mental and emotional exhaustion. The stress experienced is in a relatively long period and in a situation that demands a fairly high emotional attachment. Burnout is characterized by decreasing motivation to work, cynicism, negative attitudes, frustration, feeling rejected by the environment, a sense of failure and low selfesteem. The realizations of these changes are physical exhaustion, emotional exhaustion, and mental exhaustion.

\section{Turnover Intention}

Turnover intention is the behavior to what extent an employee intends to quit or remain with the company (Knudsen, H. K., Johnson, J. A., \& Roman, 2003). Bothma (2013) described turnover intention as the behavior to stay or leave the organization. Turnover intention is the desire of employees to voluntarily quit the organization at this time and behavior to find a new job (Thakre, 2015). Lee (2008) also explained that the turnover intention is a subjective perception of the organization's members to quit at this time with the intention of looking for another chance. Turnover intention is an individual behavior associated with the intention to voluntarily leave the organization which can also affect the status and policies of the organization and employee productivity (Issa D. A. R. M, Faiz A, 2013). Employees quitting the organization can be either caused by the organization itself or the employees' initiative. So, this may cause disruption in the operation process, teamwork dynamics and the company's performance.

Wilandha \& Wahyuningtyas

(2012) described that turnover intention is the employee's desire to voluntarily resign from the organization or company or as the movement of employees to resign from the organization. This can be seen from several indications, among others, are a tendency to leave the company, the possibility to find another job, possibility to think out of the company, possibility to think out of the company in the near time, possibility to think out of the company if there is any other better chance.

Meisler (2013) stated that turnover intention can be measured using two dimensions, namely thinking about quitting and interest in job 
Jurnal Bisnis dan Manajemen, Volume 19, No. 2, September 2018, p. 109-121

offers. Nevertheless, Wang (2014) measured turnover intention by using multiple items of questions; "I do not think I will spend my entire career with this organization, I intend to leave this organization with a short period of time, I have decided to quit this organization, I am looking at other jobs now, and if I do not get promoted soon, I will look for a job elsewhere."

Mahdi, Ahmad Faisal, Mohamad Zaid Mohd Zin, Mohd Roslan Mohd Nor (2012) defined turnover intention as employee's conscious desire and plan to leave the organization. Kuria \& Samson (2012) explained that the causes of turnover intention could be derived from internal and external factors. Internal factors which may cause turnover intention are job dissatisfaction, unfavorable environmental conditions, and long working hours with minimum payments and inadequate employee training program. Meanwhile, external factors which may result in turnover are an economic condition, better wages elsewhere, a higher payment in other industries, local and regional economic strength and a low unemployment rate. Wahyuningtyas \& Sule (2015) explained that turnover intention could be triggered by several factors, namely job satisfaction, work-life conflict, human resource department roles, and talent management.

Based on the observed phenomena in the literature review, and the results of previous studies, the framework for this study is shown in figure 1.

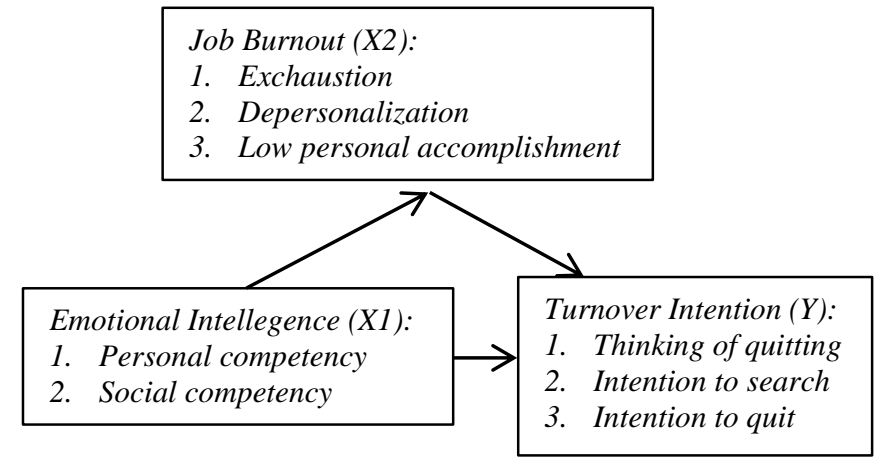

Figure 1 Research Framework

The research hypothesis is as follows:

1. Emotional intelligence affects job burnout

2. Job burnout affects turnover intention

3. Emotional intelligence affects turnover intention through job burnout

\section{METHODS}

This study is aimed at analyzing the relationship between the variables studied and to confirm the theory of Chin (2010) using PLS-SEM (Partial Least Square - Structural Equation Modeling) assisted by software SmartPLS 3.0. PLS-SEM analysis is carried out with several steps, namely: designing a structural model (inner model), designing a measurement model (outer model), constructing a path diagram, conversion of path diagram into equality, outer weight signification test, outer loading signification test, Evaluation of criteria goodness of fit through (Outer model) and (Inner model), and hypothesis testing (Ghozali, Imam \& Latan, 2015). The sampling technique used for sampling with probability sampling technique using a particular statistical approach, namely the Slovin approach, with a population of 556 employees and a $5 \%$ error margin. The sample of this research consists of 233 
Jurnal Bisnis dan Manajemen, Volume 19, No. 2, September 2018, p. 109-121

respondents who are the employees of Rural Banks (PD. BPR) in West Java province.

\section{RESULTS AND DISCUSSION}

The following shows the PLS Measurement Outer Model for the variables of Emotional Intelligence, Job Burnout, and Turnover Intention. The model consists of the validity test in PLS for testing convergent validity of outer loading value. While the Reliability Test is seen from Cronbach Alpha value.

Loading outer value of each latent variable on the indicators.

Table 1 Outer Loading (Convergent Validity)

\begin{tabular}{cccc}
\hline & $\begin{array}{c}\text { Emotional } \\
\text { Intelligence }\end{array}$ & $\begin{array}{c}\text { Job } \\
\text { Burnout }\end{array}$ & $\begin{array}{c}\text { Turnover } \\
\text { Intention }\end{array}$ \\
\hline X11 & 0.870 & & \\
X12 & $\mathbf{0 . 8 9 4}$ & & \\
X21 & & $\mathbf{0 . 8 0 7}$ & \\
X22 & & 0.804 & \\
X23 & & 0.766 & \\
Y1 & & & 0.727 \\
Y2 & & & $\mathbf{0 . 8 1 2}$ \\
Y3 & & & 0.762 \\
\hline
\end{tabular}

Table 1 shows that the outer loadings of all indicators are above 0.700 so it can be concluded that the criteria for outer loading indicator, requiring the value of over 0.600 , have been met (Chin 1998 in (Ghozali, Imam \& Latan, 2015).

Cronbach Alpha value for each latent variable is as follows:

Table 2 Cronbach Alpha

\begin{tabular}{cc}
\hline Latent Variables & Cronbach Alpha \\
\hline Emotional Intelligence & 0.715 \\
Job Burnout & 0.704 \\
Turnover Intention & 0.652 \\
\hline
\end{tabular}

Table 2 shows that the Cronbach Alpha value for each latent variable which is more than the required minimum value that is 0.600 (Hair in (Chin, 2010). Thus, the reliability criterion of Cronbach Alpha has been met.

From the test series of measuring model (outer model) above, it is shown that all criteria of the outer models have been fulfilled so the next step that will be done is the inner model analysis.

Table 3 Path Coefficients

\begin{tabular}{lccc}
\hline & $\begin{array}{c}\text { X1. } \\
\text { Emotional } \\
\text { Intelligence }\end{array}$ & $\begin{array}{c}\text { X2. Job } \\
\text { Burnout }\end{array}$ & $\begin{array}{c}\text { Y. } \\
\text { Turnover } \\
\text { Intention }\end{array}$ \\
\hline $\begin{array}{l}\text { X1. Emotional } \\
\text { Intelligence }\end{array}$ & & 0.200 & 0.153 \\
$\begin{array}{l}\text { X2. Job } \\
\text { Burnout }\end{array}$ & & & 0.285 \\
\hline
\end{tabular}

The following section presents the verification hypothesis testing, i.e., the hypothesis explaining the influence and causal relationship of the exogenous latent variable on the endogenous latent variable as has been formulated in the problem formulation section. Hypothesis testing in this study uses a bootstrapping method in SmartPLS software using the student t-test. The critical value for $\alpha=5 \%$ and $n=233$ is t-table $=$ 1.960. If the $\mathrm{t}$-calculated value is greater than 1.960 , the hypotheses are declared significant or $\mathrm{H}_{0}$ is rejected. Conversely, if the t-calculated value is less than 1.960, the hypotheses are declared insignificant or $\mathrm{H}_{0}$ is accepted.

\section{Hypotheses:}

$\mathrm{H}_{0}=0$ : Emotional intelligence does not positively influence turnover intention either directly or through job burnout. 
Jurnal Bisnis dan Manajemen, Volume 19, No. 2, September 2018, p. 109-121

$\mathrm{H}_{\mathrm{a}} \neq 0$ : Emotional intelligence positively influences turnover intention either directly or through job burnout.

The path coefficient of emotional intelligence on turnover intention, either directly or through job burnout, is visualized in Figure 1 below:

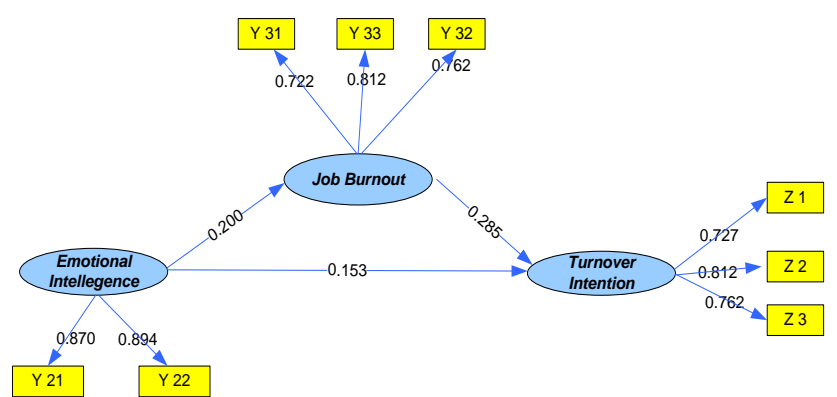

Figure 2 Path Diagram of the Hypotheses

The calculation results showed that the causality model of the emotional intelligence with Turnover Intention equals to 0.153 Emotional Intelligence + 0.977. From the results of bootstrapping, the path coefficient of 0.153 produces a t-calculated value of 2.087 . This value is greater than 1.960 , so $\mathrm{H}_{0}$ is rejected, and $\mathrm{H}_{1}$ is accepted, meaning that the EQ is proven to affect Turnover Intention positively. The strength of the effect of Emotional Intelligence on Intention Turnover is $0.153^{2} \times 100 \%=2.35 \%$ or classified as very weak (less than 19\%) (Ghozali, Imam \& Latan, 2015). Considering the influence of emotional intelligence on turnover intention of 0.153 , we can calculate the effect of emotional intelligence on turnover intention is $0.358 \times 0.153$ $=0.054$ or equivalent $\left(0.358^{2} \times 0.153^{2} \times 100 \%\right)=$ $0.67 \%$.

Empirically, in PD. BPR in West Java province, it is shown that the emotional intelligence consisting of social competence and personal competence positively affects turnover intention as characterized by the behavior of thinking to quit, job search, and intention to quit. This study supports Meisler (2013) stating that emotional intelligence has a positive relationship with the perceived organizational fairness and emotional intelligence has a negative relationship with turnover intention. Perceived organizational fairness mediates the relationship between emotional intelligence and turnover intention (Meisler, 2013). Hence, it can be concluded that high emotional intelligence may become one of the factors encouraging an employee to leave the company.

The calculation results showed that the causality model of Job Burnout on Turnover Intention equals to 0.285 Job Burnout +0.919 . From the results of bootstrapping, the path coefficient of 0.285 produces the $\mathrm{t}$-calculated value of 4.063 . This value is greater than 1.960 so $\mathrm{H}_{0}$ is rejected, and $\mathrm{H}_{1}$ is accepted, meaning that Job Burnout positively affects Turnover Intention. The significance of the effect of job burnout on turnover intention is $0.285^{2} \times 100 \%=8.13 \%$ or classified as very weak (less than 19\%) (Ghozali, Imam \& Latan, 2015).

Empirically, in PD. BPR in West Java, it is proven that job burnout as measured by exhaustion, depersonalization, and declining achievement positively affects turnover intention as characterized by the behavior of thinking to quit, job search, and intention to quit. Empirically, it is found that a high workload causes employees 
Jurnal Bisnis dan Manajemen, Volume 19, No. 2, September 2018, p. 109-121

experiencing burnout and the declining productivity is caused by the fact that employees have been in the same positions for too long. Also, high intensity in serving customers results in exhaustion to the employees. So, those things trigger the interest to leave the company or cause a high turnover intention.

This finding is consistent with Dotun et al. (2013) stating that there is a significant and positive relationship between job burnout and turnover intention.

From the findings, it is shown that there should be efforts made by the leaders to effectively manage the factors which may cause employees to remain in the company or reduce turnover intention. The employees experiencing a high emotional exhaustion tend to leave the organization and look for new career opportunities. In other words, the higher the level of job burnout is, the higher the tendency of employees to quit the organization becomes.

Employees are one of the elements of enterprise resources that must be well managed in order to be useful and contributing to the company. Employees need to be a major concern for corporate leaders because if the employees are not managed properly, there will be a lousy effect resulted such as high turnover rate. A high rate of employee turnover reflects a worse $H R$ management in that company.

Emotional Intelligence positively affects job burnout. The effect of emotional intelligence on job burnout is $4.01 \%\left(0.200^{2} \times 100 \%\right)$ or classified as very weak (less than 19\%).
Empirically, in PD. BPR in West Java, it is proven that emotional intelligence seen from the social competence and personal competence has a positive and significant influence on job burnout. This can be seen from the aspect of exhaustion, depersonalization, and a declining achievement.

\section{CONCLUSION}

Based on the research results and discussion described previously, it can be concluded that emotional intelligence has a positive influence on turnover intention. It can be seen from the indicators of emotional intelligence which have a high value, especially regarding social competence characterized by empathy, motivation to be a leader, ability to change, and maintaining a relationship with co-workers. However, this is different for the indicators of emotional intelligence on the aspects of personal competence, such as self-emotion understanding, self-strengths and weaknesses, self-capability understanding, and openness at work which are the indicators with a small effect on turnover intention.

Emotional intelligence positively affects job burnout. This is described in the high indicators of emotional intelligence, especially in the social competence aspects, such as empathy, motivation to be a leader, ability to change, and maintaining a relationship with co-workers. However, the indicators of emotional intelligence on the aspects of personal competence, such as self-emotion understanding, self-strengths and weaknesses, self-capability understanding, and 
Jurnal Bisnis dan Manajemen, Volume 19, No. 2, September 2018, p. 109-121

openness at work are the indicators with a tiny effect on job burnout.

Job burnout positively affects turnover intention. This is reflected in the indicators of job burnout, namely exhaustion, depersonalization, and declining work performance. Exhaustion is characterized by boredom and feeling of too much workload while depersonalization is characterized by the selfishness (always has thinking that he or she is better than others) and ignorance of other people's performance. Meanwhile, declining work performance is characterized by self-efficacy and low productivity, which are the factors of turnover intention in the company.

From the research results we provide some recommendation that the further research can be done by looking at the limitations in this study, namely; the limitation about the object of research that only use the respondents on employees in PD. BPR Banks in West Java. So, further research can be carried out by using larger object of research to get more general results on factors affecting turnover intention.

Another limitation is on the research object using employees PD. BPR Banks in West Java as research respondents which are homogeneous. Thus, the variations in responses from respondents on other objects such as conventional commercial banks, or sharia banks cannot be identified. The results of this study cannot be generalized to cases outside the object of research, because it only uses the object of employees in PD. Bank BPR West Java.
Further research that complements existing variables in this study needs to be done to further refine the understanding of the understanding of other factors that influence employee turnover intention in addition to variables that have been studied, such as; change, development, and culture.

\section{REFERENCES}

Bank Indonesia. (2014). Statistik Perbankan Indonesia. Bank Indonesia.

BarOn, R. (1997). Bar-On Emotional Quotient Inventory: User's manual (Toronto). MultiHealth Systems.

BarOn R. \& Parker, J. (2000). Handbook of emotional intelligence. San Francisco: Jossey-Bass.

Bothma, C. F. . and G. R. (2013). The validation of the turnover intention scale. SA Journal of Human Resource Management, 11, 1-12.

Chen, C. F., \& Yu, T. (2014). Effects of positive vs negative forces on the burnoutcommitment-turnover relationship. Journal of Service Management, 25(3), 388-410. https://doi.org/10.1108/JOSM-01-2012-0003

Chin, W. W. (2010). Handbook of Partial Least Squares: Concepts, methods and applications. Berlin, Heidelberg: Springer.।.

Chiva.R \& Alegre.J. (2008). Emotional intelligence and job satisfaction: the role of organizational learning capability. Personnel Review, 37(6), 680-701.

Demerouti, E., Nachreiner, F., Bakker, A. B., \& Schaufeli, W. B. (2001). The job demandsresources model of burnout. Journal of Applied Psychology, 86(3), 499-512. https://doi.org/10.1037/0021-9010.86.3.499

Dotun, F. O., Nneka, A. A., \& Akinlolu, A. A. (2013). Job burnout and intention to quit: an empirical study of the Nigeria Police. International Journal of Business \& Economic Development, 1(3), 25-36. Retrieved from https://lopes.idm.oclc.org/login?url=http://sea rch.ebscohost.com/login.aspx?direct=true $\& d$ $b=b$ th\&AN=92945639\&site $=$ eds- 
Jurnal Bisnis dan Manajemen, Volume 19, No. 2, September 2018, p. 109-121

live $\&$ scope $=$ site

Galit Meisler. (2013). Empirical Exploration of The Relationship Between Emotional Intelligence, Perceived Organizational Justice and Turnover Intentions. Employee Relations, 35(4), 441-455. https://doi.org/10.1108/ER-05-2012-0041

Ghozali, Imam \& Latan, H. (2015). Partial Least Squares, Konsep, Teknik dan Aplikasi SmartPLS 3.0 M3 untuk Penelitian Empiris. Semarang, Indonesia: Badan Penerbit Universitas Dipenogoro.

Green, A. E., Miller, E. A., \& Aarons, G. A. (2013). Transformational leadership moderates the relationship between emotional exhaustion and turnover intention among community mental health providers. Community Mental Health Journal, 49(4), 373-379. https://doi.org/10.1007/s10597011-9463-0

Hakanen, J. J., Bakker, A. B., \& Schaufeli, W. B. (2006). Burnout and work engagement among teachers. Journal of School Psychology, 43(6), 495-513. https://doi.org/10.1016/j.jsp.2005.11.001

Heru Santoso. (2012). Strategi Pengembangan SDM sebagai Upaya Meningkatkan Daya Saing BPR. Jakarta: Bank Indonesia.

Issa D. A. R. M, Faiz A, G. H. M. (2013). Job Satisfaction And Turnover Intention Bassed On Sales Person Standpoint. Middle-East Journal of Scientific Research, 14(4), 525531.

Khanifar, H., Maleki, H., Nazari, K., \& Emami, M. (2012). The Study of the Relation between Emotional (Case Study of Staff at State Universities in Ghom). Interdisciplinary Journal of Contemporary Research in Business, 3(9), 564-582.

Kim, H. J., Shin, K. H., \& Swanger, N. (2009). Burnout and engagement: A comparative analysis using the Big Five personality dimensions. International Journal of Hospitality Management, 28(1), 96-104. https://doi.org/10.1016/j.ijhm.2008.06.001

Knudsen, H. K., Johnson, J. A., \& Roman, P. M. (2003). Retaining Counseling Staff at Substance Abuse Treatment Centers: Effects of Management Practices. Journal of Substance Abuse Treatment, 24, 129-135.
Kreitner, R., \& Kinicki, A. (2014). Organizational behaviour. NewYork: McGraw Hill.

Kuria, Samson, O. A. and P. M. W. (2012). Assessment of Cause of Labour Turnover in Three and Five Star-Rated Hotels in Kenya. International Journal of Business and Social Science, 15(3), 311-317.

Lee, W.-J. (2008). A Pilot Survey of Turnover Intention and Its Determinants among Adult Probation Line Officers in Texas. Funded Research by the Agency of Research Enhancement Grant of Texas State.

Mahdi, Ahmad Faisal, Mohamad Zaid Mohd Zin, Mohd Roslan Mohd Nor, A. A. S. and A. S. A. N. (2012). The Relationship Between Job Satisfaction and Turnover Intention. American Journal of Applied Sciences, 9 , 1518-1526.

Maslach, C., \& Leiter, M. P. (2008). The Truth About Burnout: How Organizations Cause Personal Stress and What To Do About it. San Francisco: Jossey-Bass.

Mayende, T. S., \& Musenze, I. A. (2014). Personality Dimensions and Job Turnover Intentions: Findings from a University Context. International Journal of ..., 4(2), 153-164. Retrieved from http://ijmbr.srbiau.ac.ir/article_2493_0.html

Meisler, G. (2013). Empirical exploration of the relationship between emotional intelligence, perceived organizational justice and turnover intentions. Employee Relations, 35(4), 441455. https://doi.org/10.1108/ER-05-20120041

Palmer, B., Donaldson, C., \& Stough, C. (2008). Emotional intelligence and life satisfaction. Emotional Intelligence: Perspectives on Educational and Positive Psychology., 336, 131-143. Retrieved from http://search.ebscohost.com/login.aspx?direct $=$ true $\& \mathrm{db}=$ psyh $\& A N=2009-04345$ $008 \&$ site $=$ ehost-live \&scope $=$ site

Pishghadam, R., \& Sahebjam, S. (2012). Personality and Emotional Intelligence in Teacher Burnout. The Spanish Journal of Psychology, 15(01), 227-236. https://doi.org/10.5209/rev_SJOP.2012.v15.n 1.37314

Ratri Wahyuningtyas, Ernie Tisnawati Sule, M. K. and I. S. (2015). Employee Turnover 
Jurnal Bisnis dan Manajemen, Volume 19, No. 2, September 2018, p. 109-121

Intentions in Hotel : How to reduce it?

Advanced Science Letters, 21, 719-722.

Ravichandran, K., Arasu, R., \& Arun Kumar, S.

(2011). The Impact of Emotional Intelligence

on Employee Work Engagement Behavior:

An Empirical Study. International Journal of

Business and Management, 6(11), 157-170.

https://doi.org/10.5539/ijbm.v6n11p157

Robbins, S. P. (2007). Organizational Behavior

(12th ed.). New Jersey: Prentice Hall

International.

Shirom, A., Melamed, S., Toker, S., Berliner, S., \& Shapira, I. (2005). Burnout, Mental and Physical Health: A review of The Evidence and A Proposed Explanatory Model.

International Review of Industrial and

Organizational Psychology, 20, 269-309.

Shirom, A. (2003). The Effects of Work-Related

Stress on Health. In M. J. Schabracq, J. A. M.

Winnubst, \& C. L.

Thakre, N. (2015). Organizational Commitment and Turnover Intention in BPO- ITeS and Retail Sector Employees, 10(1), 89-98.

Wahyuni, A. S., Zaika, Y., \& Anwar, R. (2014). Analisis Faktor-Faktor Yang Mempengaruhi Turnover Intention ( Keinginan Berpindah ) Karyawan. Jurnal Rekayasa Sipil, 8(2), 8995.

Wang, E. S. T. (2014). The effects of relationship bonds on emotional exhaustion and turnover intentions in frontline employees. Journal of Services Marketing, 28(4), 319-330. https://doi.org/10.1108/JSM-11-2012-0217

Wilandha, P. F., \& Wahyuningtyas, R. (2012). The Influence of Job Satisfaction and Organizational Commitment to Employee Turnover Intentions in H Company, (2011), 978-979. 